\title{
RANCANG BANGUN MODEL KOMPRESI DAN TARIK PERMODELAN SANDBOX DAN MANFAATNYA
}

\author{
F. Fahrudin*), Dimas Asmarakandy \\ Program Studi Teknik Geologi, Fakultas Teknik, Universitas Diponegoro, \\ Jl. Prof. Soedarto, SH, Kampus Undip Tembalang, Semarang, Indonesia 50275
}

\begin{abstract}
Abstrak
Permodelan sandbox dibuat dengan system tektonik konvergen dan divergen dengan menggunakan pergerakan satu sumbu. Permodelan ini bertujuan untuk membuat alat mesin sandbox yang bisa digunakan untuk penelitian dan pengajaran. Mesin berhasil dibuat dan sudah diujicobakan. Ujicoba dengan menggunakan satu lapisan pasir yang diambil dari Formasi Ngrayong. Percobaan selanjutnya dengan beberapa lapisan. Percobaan dilakukan dengan pengamatan yang meliputi pengamatan permukaan dan penampang verikal. Pengamatan yang aspek morfologi, kelurusan struktur, dan perkembangan sesar yang terbentuk. Hasil percobaan menunjukkan bahwa pembentukan morfologi sangat berkaitan dengan pembentukan sesar. Struktur sesar dengan pola forward propagating thrust faults. Sesar tersebut disebabkan imbrikasi. Lipatan yang terbentuk akibat mekanisme propagasi sesar.
\end{abstract}

Kata kunci: sandbox; sesar naik; morfologi

\begin{abstract}
[Design of Compression and Extensional of the Sandbox Model and Its Benefit] Divergent and convergent tectonic sytem can be studied from the sandbox modelling. This model has a axis of movement. Sandbox models itends to study the progress of structural geology such as fault and fold. We successfully made machine of sandbox. This machine has basal detachment from duraluminum. Material for model is taken by loose sand from Ngrayong Formation. This experiment focused to observation about morphology in surface and thrust or backthrust in subsurface. This experiment has compression system. Result of model was that morphological sequences associated with fault sequences. Fault is formed to have the pattern of forward propagating thrust faults. It's caused by imbricate thrust system. Folding is formed by the mechanism of fault propagation folding.
\end{abstract}

Keywords: sandbox; thrust fault; morphology

\section{Pendahuluan}

Pemodelan analog bertujuan untuk menyederhanakan contoh di alam dan didasarkan pada keserupaan gejala yang ditunjukkan oleh masalah yang dimiliki oleh model (Purwasasmita, 2000). Kondisi awal sebelum deformasi dan setelah deformasi dapat dibandingkan dengan pemodelan analog. Pemodelan analog dengan sandbox digunakan untuk mempelajari pola dan geometri suatu hasil deformasi getas (brittle) (Sapiie dan Harsolumakso, 2000).

Penelitian ini bertujuan untuk meneliti perkembangan morfologi, pola dan distribusi struktur pada sistem tektonik konvergen dan membuat model rancangan bangun kompresi dan tarik permodelan sandbox.

\section{Metode Penelitian}

Pembuatan desain fisik mesin sandbox terbagi menjadi tiga yaitu perakitan mekanik, perakitan secara elektrik, dan perakitan secara digital. Setelah mesin sandbox jadi kemudian dilakukan percobaan sistem kompresi dengan material pasir lepas dan membandingan dengan kondisi di alam.

Material yang digunakan adalah pasir kuarsa Formasi Ngrayong berukuran 60-80 mesh $( \pm 0,178$ $\mathrm{mm})$ sudut geser dalam sekitar $29^{\circ}$ dan densitas 1,59 $\mathrm{gr} / \mathrm{cm}^{3}$. Sedang bahan kedua pasir kuarsa berukuran $30-50$ mesh $( \pm 0,257 \mathrm{~mm})$ dengan sudut geser dalam sekitar $32^{\circ}$ dan densitas $1,65 \mathrm{gr} / \mathrm{cm}^{3}$. Lapisan percobaan ada 6 lapis dengan ketebalan lapisan sama yaitu $0,5 \mathrm{~cm}$ (Tabel 1). Kecepatan mesin sandbox $3 \mathrm{~Hz}$ atau setara dengan $0,5 \mathrm{~mm} / \mathrm{menit}$.

\section{Dasar Teori Pemodelan Sandbox}

Pemodelan sandbox digunakan untuk mensimulasikan deformasi pada batuan dengan kondisi getas (Hubbert, 1951; Cloos, 1955; McClay, 1990). Deformasi pada kondisi getas akan mengikuti Hukum Gangguan dari Coulomb. Berdasarkan hukum tersebut, mekanisme dalam pengertian dasar tegasan dan hubungannya dengan geometri yang terbentuk 
digambarkan dengan menggunakan diagram Mohr. McClay (1996) menyatakan bahwa hukum Gangguan dari Coulomb didasarkan pada model dinamik dan mekanika yang dikembangkan oleh Coulomb (1773) dan Mohr (1990). Hukum tersebut dirumuskan dengan Persamaan (1) sebagai berikut:

$\sigma_{c}=\sigma_{o}+\tan \phi\left(\sigma_{n}\right)$

Dimana: $\sigma_{c}=$ tegasan gerus kritis; $\sigma_{o}=$ kohesivitas; $\tan$ $\phi=$ koefisien gesek dalam; $\sigma_{n}=$ tegasan normal. Persamaan ini menunjukkan tinggi dan kemiringan garis amplop keretakan untuk batuan pada saat mengalami kompresi dan tensional serta digambarkan pada diagram Mohr.

Tabel 1. Lapisan Model

\begin{tabular}{llc}
\hline No & \multicolumn{1}{c}{ Lapisan/Warna } & $\begin{array}{c}\text { Ukuran Butir } \\
\text { (mesh) }\end{array}$ \\
\hline 1 & Keenam/coklat & $60-80$ \\
2 & Kelima/hijau & $30-50$ \\
3 & Keempat/coklat & $60-80$ \\
4 & Ketiga/merah & $30-50$ \\
5 & Kedua/coklat & $60-80$ \\
6 & Pertama/hijau & $30-50$ \\
\hline
\end{tabular}

Model sesar naik yang terbentuk pada zona subduksi mengalami propagasi seiringan dengan pemendekan dengan membentuk prowedge (Gambar 1). Pembentuk sesar naik sangat dipengaruhi oleh basal detachment dan struktur material penyusun model.

Gambar 1. Model Prowedge dan Pembentuk Thrust

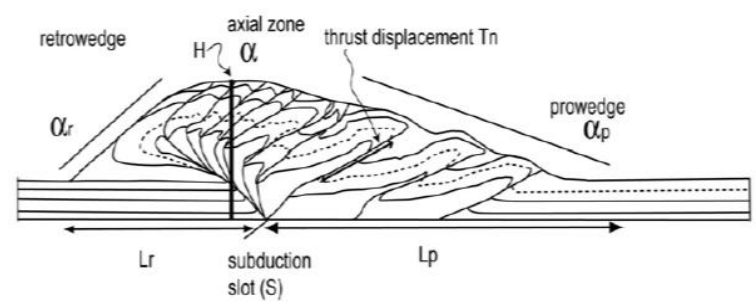

Pada Zona Subduksi (Bigi dkk., 2010)

\section{Hasil dan Pembahasan}

\section{Mesin Sandbox}

Proses produksi dibagi menjadi dua tempat satu berada di Bandung untuk komponen dengan bahan durallium untuk struktur dalam dan pemegang kaca dan pengerjaan di Semarang untuk struktur utama, pengelasan struktur utama dan perakitan keseluruhan komponen sandbox. Bahan durallium sebagai basal detachment mempunyai komposisi aluminium dengan tembaga $4 \%$.

\section{Morfologi dan Sesar}

Percobaan mengamati morfologi, pembentukan sesar di dinding selatan dan utara, serta sudut prowedge. Pemendekan (shortening) yang diamati dengan nilai $3,5 \%, 10 \%, 21 \%$ dan $28 \%$. Rekapitulasi data tabulasi pembentukan sesar pada Tabel 2 dan data pengukuran dip sesar vs pemendekan pada Tabel 3 . Sedangkan visualisasi morfologi pada Gambar 2 dan pembentukan sesar pada penampang dinding selatan (ds) dan dinding utara (du) pada Gambar 3 dan 4.

Awal mula percobaan, membentuk morfologi tinggi (ridge) yang memanjang dan terpusat di tengah (Gambar 2a). Ridge ini berhubungan pembentukan sesar yang dimulai juga dari tengah. Setelah itu, ridge berkembangan sampai ke tepi.

Percobaan ini menghasilkan tiga zona ridge yaitu ridge pertama (ZR1) (kelurusan no. 1, 4, dan 5), ridge kedua (ZR2) (kelurusan no 9) dan ridge ketiga (ZR3) (kleurusan no. 10). Jarak antar ridge sekitar 5 cm (Gambar 2a, 2b, 2c, 2d).

Sesar yang terbentuk berupa thrust dan backthrust yang mengalami imbrikasi dengan dipengaruhi oleh basal detachment. Thrust yang terbentuk berupa imbrikasi dengan perkembangan ke depan (forward breaking thrust). Umumnya model forward breaking thrust, akan menghasilkan zona tidak aktif di belakang atau zona aktif berada di depan. Pada percobaan ini, saat pemendekan $28 \%$ penampang ds menghasilkan zona tidak aktif disekitar zona ridge pertama, sedangkan pada du disekitar zona ridge pertama masih aktif. Di zona ini terbentuk tf 7 (thrust ke-7).

Jumlah sesar yang terbentuk mengikuti fungsi waktu pemendekan baik penampang dinding utara dan selatan (Gambar 4 dan 5). Jumlah sesar sampai pada pemendekan $28 \%$ antara dinding utara dan selatan sama adalah 12 buah, dengan 3 sesar mayor. Sesar mayor pada kenampakan permukaan mempunyai nomor 1, 9, dan 10. Tiga sesar mayor (thrust) akan membentuk tiga zona ridge.

\section{Prowedge, Spasi Sesar, dan Sesar Mayor.}

Sudut prowedge yang terbentuk pada penampang ds adalah $13^{\circ}$ sampai $7^{\circ}$ sedangkan penampang du adalah $22^{\circ}$ sampai $8^{\circ}$. Sudut prowedge yang terbentuk semakin kecil seiring dengan penambahan pemendekan (Tabel 4).

Spasi sesar yang terbentuk pada penampang ds antara $1,3 \mathrm{~cm}$ sampai $2,95 \mathrm{~cm}$, pada penampang du antara 1,49 $\mathrm{cm}$ sampai $2,64 \mathrm{~cm}$. Pada pemendekan $21 \%$ dan $28 \%$, spasi sesar antar sesar semakin besar secara dengan arah perkembangan ke depan dari thrust.

Sesar Mayor pada penampang dinding selatan meliputi tf 1 , tf 3 dan tf 5 , pada penampang dinding utara meliputi tf 1 , tf 4 dan tf 6 . Sesar mayor ini yang membatas antara zona ridge. 
Tabel 2. Tabulasi Pembentukan Sesar

\begin{tabular}{ccccc}
\hline No & $\begin{array}{c}\text { Pemendekan } \\
(\%)\end{array}$ & $\begin{array}{c}\text { Kenampakan sesar di } \\
\text { permukaan }\end{array}$ & $\begin{array}{c}\text { Kenampakan sesar di } \\
\text { ds }\end{array}$ & $\begin{array}{c}\text { Kenampakan sesar di } \\
\text { du }\end{array}$ \\
\hline
\end{tabular}

\begin{tabular}{|c|c|c|c|c|}
\hline 1 & 3,5 & 1 & bt $1, \mathrm{tf} 1$ & bt1, tf1 \\
\hline 2 & 10,5 & 1,4 & $\mathrm{bt} 1, \mathrm{bt} 2, \mathrm{tf} 1, \mathrm{tf} 2$ & $\mathrm{bt} 1, \mathrm{bt} 2, \mathrm{tf} 1, \mathrm{tf} 2, \mathrm{tf} 3$ \\
\hline 3 & 21 & $1,4,5,9$ & $\begin{array}{l}\text { bt } 1, \text { bt } 2, \text { bt } 3, \text { bt } 4, \text { bt } 5 \text {, } \\
\text { tf } 1, \mathrm{tf} 2, \mathrm{tf} 3, \mathrm{tf} 4 \\
\text { bt } 1, \mathrm{bt} 2, \mathrm{bt} 3, \mathrm{bt} 4, \mathrm{bt} 5 \\
\mathrm{bt} 6, \mathrm{tf} 1, \mathrm{tf} 2, \mathrm{tf} 3, \mathrm{tf} 4, \mathrm{tf} 5\end{array}$ & $\begin{array}{l}\mathrm{bt} 1, \mathrm{bt} 2, \mathrm{bt} 3, \mathrm{bt} 4, \mathrm{tf} 1, \mathrm{tf} 2 \\
\mathrm{tf} 3, \mathrm{tf} 4, \mathrm{tf} 5\end{array}$ \\
\hline 4 & 28 & $1,4,5,9,10$ & & $\begin{array}{l}\text { bt } 1, \text { bt } 2, \text { bt } 3, \text { bt } 4, \text { bt } 5, \text { tf } 1, \\
\text { tf } 2, \mathrm{tf} 3, \mathrm{tf} 4, \mathrm{tf} 5, \mathrm{tf} 6, \mathrm{tf} 7\end{array}$ \\
\hline
\end{tabular}

Ket $:$ bt $=$ backthrust; $\mathrm{tf}=$ thrust

Tabel 3. Pengukuran dip sesar vs pemendekan

\begin{tabular}{|c|c|c|c|c|c|c|c|c|c|}
\hline \multirow{2}{*}{ Pemendekan } & \multicolumn{2}{|c|}{ thrust 1} & \multicolumn{2}{|c|}{ back thrust 1} & \multirow{2}{*}{ Pemendekan } & \multicolumn{2}{|c|}{ thrust 4} & \multicolumn{2}{|c|}{ back thrust 4} \\
\hline & $\mathrm{du}\left({ }^{0}\right)$ & $\mathrm{ds}\left({ }^{0}\right)$ & $\mathrm{du}\left({ }^{0}\right)$ & ds $\left({ }^{0}\right)$ & & $\mathrm{du}\left({ }^{0}\right)$ & $\mathrm{ds}\left({ }^{0}\right)$ & $\mathrm{du}\left({ }^{0}\right)$ & ds $\left({ }^{0}\right)$ \\
\hline 3,5 & 33 & 32 & 37 & 37 & 3,5 & & & & \\
\hline 7 & 31 & 30 & 42 & 43 & 7 & & & & \\
\hline 10,5 & 33 & 34 & 44 & 45 & 10,5 & & & & \\
\hline 14 & 38 & 45 & 45 & 48 & 14 & 34 & 30 & 40 & 37 \\
\hline 17,5 & 38 & 50 & 48 & 50 & 17,5 & 38 & 38 & 42 & 38 \\
\hline 21 & 47 & 55 & 50 & 50 & 21 & 28 & 38 & 42 & 40 \\
\hline 24,5 & 48 & 56 & 50 & 52 & 24,5 & 27 & 38 & 45 & 42 \\
\hline 28 & 48 & 56 & 50 & 52 & 28 & 29 & 38 & 46 & 42 \\
\hline 31,5 & 48 & 56 & 52 & 52 & 31,5 & 30 & 38 & 46 & 43 \\
\hline 35 & 48 & 56 & 52 & 52 & 35 & 30 & 38 & 46 & 44 \\
\hline \multirow{2}{*}{ Pemendekan } & \multicolumn{2}{|c|}{ thrust 2} & \multicolumn{2}{|c|}{ back thrust 2} & Pemendekan & \multicolumn{2}{|c|}{ thrust 5} & \multicolumn{2}{|c|}{ back thrust 5} \\
\hline & $\mathrm{du}\left({ }^{0}\right)$ & ds $\left({ }^{0}\right)$ & $\mathrm{du}\left({ }^{0}\right)$ & ds $\left({ }^{0}\right)$ & Pemendekan & $\mathrm{du}\left({ }^{0}\right)$ & ds $\left({ }^{0}\right)$ & $\operatorname{du}\left({ }^{0}\right)$ & ds $\left({ }^{0}\right)$ \\
\hline 3,5 & & & 45 & 34 & 3,5 & & & & \\
\hline 7 & 25 & 22 & 48 & 36 & 7 & & & & \\
\hline 10,5 & 27 & 28 & 47 & 38 & 10,5 & & & & \\
\hline 14 & 34 & 40 & 48 & 40 & 14 & & & & \\
\hline 17,5 & 35 & 48 & 52 & 45 & 17,5 & 25 & & & \\
\hline 21 & 40 & 50 & 54 & 50 & 21 & 25 & & & \\
\hline 24,5 & 44 & 48 & 54 & 52 & 24,5 & 28 & 32 & & 39 \\
\hline 28 & 45 & 48 & 55 & 52 & 28 & 28 & 32 & & 37 \\
\hline 31,5 & 45 & 50 & 55 & 52 & 31,5 & 32 & 30 & 35 & 37 \\
\hline 35 & 45 & 50 & 55 & 52 & 35 & 35 & 24 & 35 & 38 \\
\hline
\end{tabular}


Teknik, 36 (1), 2015, 48

\begin{tabular}{ccccc}
\hline \multirow{2}{*}{ Pemendekan } & \multicolumn{2}{c}{ thrust 3} & \multicolumn{2}{c}{ back thrust 3 } \\
\cline { 2 - 5 } & $\mathrm{du}\left({ }^{0}\right)$ & $\mathrm{ds}\left({ }^{0}\right)$ & $\mathrm{du}\left({ }^{0}\right)$ & $\mathrm{ds}\left({ }^{0}\right)$ \\
\hline 3,5 & & & & \\
7 & 25 & 32 & & \\
10,5 & 34 & 32 & 35 & 36 \\
14 & 36 & 30 & 40 & 39 \\
17,5 & 38 & 20 & 41 & 41 \\
21 & 40 & 20 & 38 & 42 \\
24,5 & 42 & 19 & 38 & 42 \\
28 & 42 & 20 & 40 & 42 \\
31,5 & 42 & 20 & 40 & 42 \\
35 & & & & \\
\hline
\end{tabular}

\begin{tabular}{|c|c|c|c|c|}
\hline \multirow{2}{*}{ Pemendekan } & \multicolumn{2}{|c|}{ thrust 6} & \multicolumn{2}{|c|}{ back thrust 6} \\
\hline & $\mathrm{du}\left({ }^{0}\right)$ & ds $\left({ }^{0}\right)$ & $\mathrm{du}\left({ }^{0}\right)$ & $\mathrm{ds}\left({ }^{0}\right)$ \\
\hline $\begin{array}{c}3,5 \\
7\end{array}$ & & & & \\
\hline 10,5 & & & & \\
\hline 14 & & & & \\
\hline 17,5 & & & & \\
\hline 21 & & & & \\
\hline 24,5 & 30 & & & \\
\hline 28 & 30 & & & \\
\hline 31,5 & 25 & & & 30 \\
\hline 35 & 20 & & & 30 \\
\hline
\end{tabular}

\begin{tabular}{|c|c|c|c|c|c|c|c|}
\hline \multirow{3}{*}{ Keterangan } & \multirow{4}{*}{$\begin{array}{l}\mathrm{du}= \\
\mathrm{ds}=\end{array}$} & \multirow{4}{*}{$\begin{array}{l}\text { Dinding bagian sebelah utara } \\
\text { Dinding bagian sebelah selatan }\end{array}$} & \multirow{3}{*}{ Pemendekan } & \multirow{2}{*}{\multicolumn{2}{|c|}{ thrust 7}} & \multirow{2}{*}{\multicolumn{2}{|c|}{ back thrust 7}} \\
\hline & & & & & & & \\
\hline & & & & $\mathrm{du}\left({ }^{0}\right)$ & ds $\left({ }^{0}\right)$ & $\mathrm{du}\left({ }^{0}\right)$ & ds $\left({ }^{0}\right)$ \\
\hline & & & $\begin{array}{c}3,5 \\
7\end{array}$ & & & & \\
\hline & & & 10,5 & & & & \\
\hline & & & 14 & & & & \\
\hline & & & 17,5 & & & & \\
\hline & & & 21 & & & & \\
\hline & & & 24,5 & 20 & & & \\
\hline & & & 28 & 20 & & & \\
\hline & & & 31,5 & 20 & & & \\
\hline & & & 35 & 20 & & & 30 \\
\hline
\end{tabular}
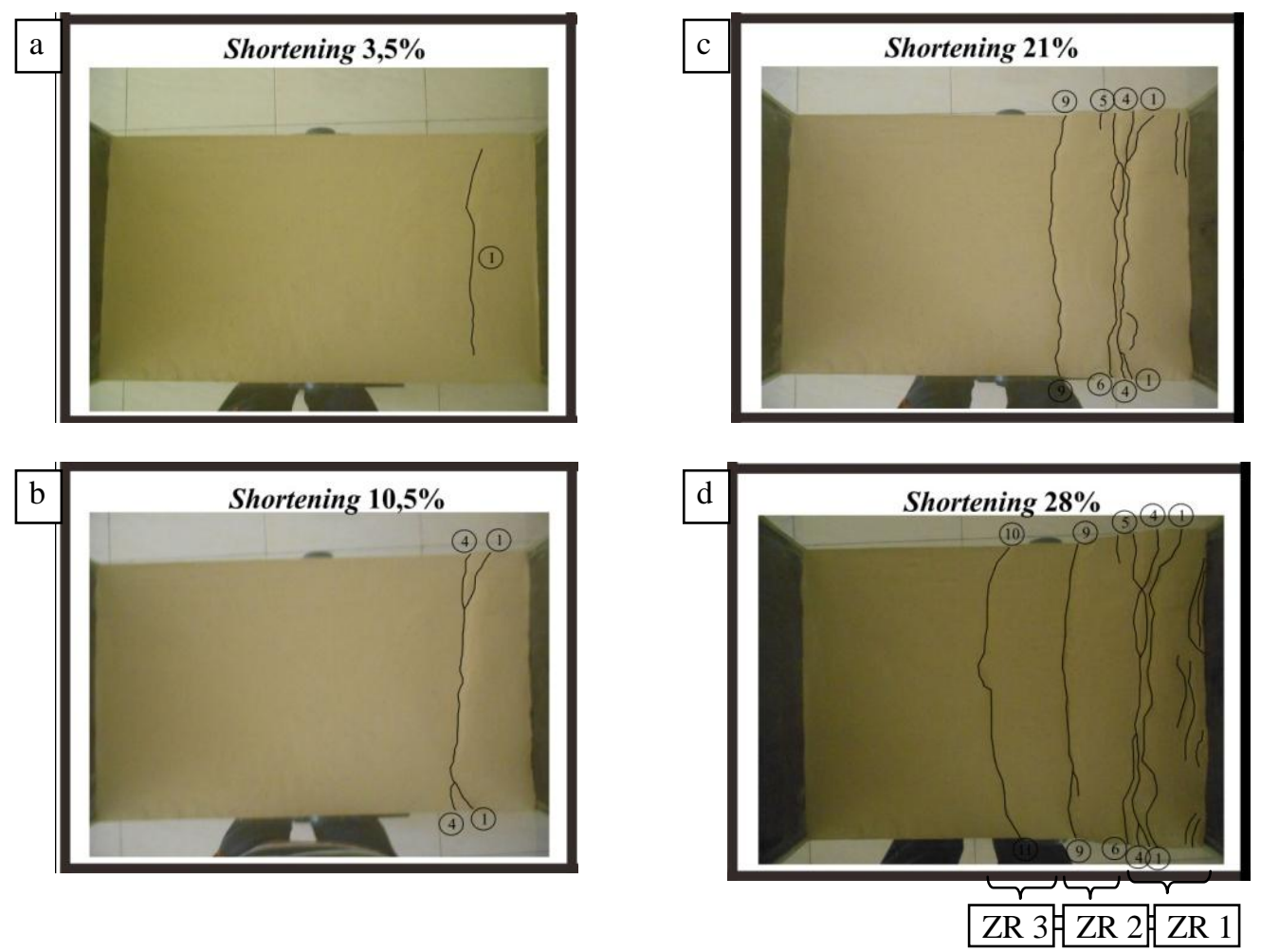

Gambar 2. Morfologi sesar dan pembagian zona ridge. 
Kemiringan Sesar (Fault Dip) dan Pemendekan.

Pada pemendekan 3,5\% (ds dan du), terbentuk backthrust (bt 1) dan thrust (tf 1) yang membentuk tinggian (bagian dari zona ridge pertama). Tinggian ini membentuk antiklin dengan sudut kemiringan lapisan yang sangat landai antara $0-3^{\circ}$. Lipatan landai ini terbentuk dengan mekanisme fault propagation folding. Sayap lipatan yang terpotong tf 1 berarah SE. Kemiringan sesar tf 1 yaitu $32^{\circ}-33^{\circ}$, bt 1 adalah $37^{\circ}$.

Pada pemendekan $10,5 \%$ (ds dan du), material inti (lapisan paling bawah) dari back thrust dan thrust naik, tetapi bentuk geometri nya berbeda (Gambar $4 \mathrm{~b}$ dan 5b). Naiknya lapisan inti ini disebabkan oleh basal detachment. Sekuen ini masih membentuk zona ridge petama hanya sekuen sesar nya bertambah. Pada ds, sekuen sesar terdiri atas bt 1 , bt 2 , tf 1 dan tf 2 . Pada du, sekuen sesar terdiri atas bt 1 , bt 2 , tf 1 , tf 2 dan tf3. Pada ds, kemiringan bidang sesar back thrust yaitu $44^{\circ}-47^{\circ}$ dan thrust yaitu $34^{\circ}-28^{\circ}$.

Pada pemendekan $21 \%$ (ds dan du), material inti pada ds berbeda dengan du. Lapisan inti pada ds, saling terpisah. Lapisan inti yang kedua menghasilkan sesar mayor tf 3 sebagai batas zona ridge kedua. Sedangkan pada du, lapisan inti masih satu lapisan, hanya bentuk bagian atas runcing-runcing, bentuk runcing ini sebagai jalur sesar (Gambar 4c dan 5c). Sekuen yang mendekati kesesuaian bentuk imbricate thrust system terjadi pada ds. Sekuen ini menghasilkan zona ridge pertama dan kedua. Sekuen ZR 1 terdiri atas bt 1, bt 2, bt 5, tf 1 , dan tf 2 . Sekuen ZR 2 terdiri atas bt 3 , bt 4 , tf 3 , dan tf 4 . Pada ZR 1, kemiringan lapisan yang terpotong tf 1 berubah ke arah $\mathrm{NE}$ mengikuti perubahan kemiringan sesar tf 1 . Sesar tf 1 berubah menjadi reverse fault. Reverse fault membentuk drag reverse dengan bentuk concave. Kemiringan bidang sesar backthrust yaitu $50^{\circ}$ dan thrust yaitu $55^{\circ}-50^{\circ}$. Pada ZR 2 terbentuk tinggian kedua dengan sudut kemiringan lapisan antiklin yang sangat landai antara $0-3^{\circ}$. Lipatan landai ini terbentuk dengan mekanisme fault propagation folding. Sayap lipatan yang terpotong tf 3 berarah SE. Sekuen ZR 2 terdiri atas tf 3 , tf 4 , bt 3 dan bt 4 . Saat propagasi sekuen ZR 2, pada ZR 1 masih aktif hal ini ditandai terbentuknya bt 5 dan kenaikan kemiringan bidang tf dan bt. Kemiringan bidang sesar tf 3 adalah $20^{\circ}$, bt 3 dan bt 4 adalah $41^{\circ}$ dan $40^{\circ}$.

Pada pemendekan $28 \%$ (ds dan du), material inti pada ds berbeda dengan du. Lapisan inti pada ds, saling terpisah. Ada 3 lapisan inti, lapisan inti yang ketiga menghasilkan sesar mayor tf 5 sebagai batas zona ridge ketiga. Sedangkan pada du, lapisan inti ada dua, lapisan inti pertama menghasilkan ZR 1 dan ZR2, sedangkan lapisan inti kedua menghasilkan ZR 3 dengan sesar mayor tf 6 (Gambar 4d dan 5d). Sekuen yang mendekati kesesuaian bentuk imbricate thrust system terjadi pada ds dan du. Sekuen ini menghasilkan zona ridge ketiga. Pada ds, sekuen ZR 3 terdiri atas bt 6 dan tf 5 . Sekuen ini membentuk tinggian dengan antiklin yang mempunyai kemiringan lapisan $0-3^{\circ}$. Kemiringan sesar tf 5 yaitu $32^{\circ}$. Lipatan landai ini terbentuk dengan mekanisme fault propagation folding. Sayap lipatan yang terpotong tf 5 berarah SE. Saat propagasi sekuen ZR 3, lapisan batuan antklin pada ZR 2 semakin besar sekitar 5-8, sudut prowedge semakin tinggi dan panjangprowedge semakin kecil tetapi tinggian semakin besar. Kemiringan sesar mayor tf 3 adalah $20^{\circ}$, masih berupa thrust.

Pada du, sekuen ZR 3 terdiri atas bt 5 dan tf 6 . Sekuen ini tidak membentuk tinggian tetapi terdapat yang dikontrol thrust dengan sesar mayor tf 6 . Kemiringan sesar tf 6 yaitu $30^{\circ}$. Saat propagasi sekuen ZR 3, sudut prowedge semakin tinggi dan panjang prowedge semakin kecil tetapi tinggian semakin besar. Ketika propagasi ZR 3, ZR 1 dan ZR 2 juga masih aktif.

Gambar 5 dan 7 pada penampang du, menunjukan bahwa tf 1 , tf 2 , tf 3 dan tf 5 dip sesar semakin naik seiring dengan penambahan pemendekan, sedangkan tf 4 dan 6 dip sesarnya semakin turun seiring dengan penambahan pemendekan. Bt 1, bt 2, bt 3, bt 4 dengan penambahan pemendekan nilai dip sesarnya semakin naik. Gambar 6 dan 8 pada penampang ds, bahwa tf 1 , tf 2 , dan tf 4 dip sesar semakin naik seiring dengan penambahan pemendekan, sedangkan tf 3 dan 5 dip sesarnya semakin turun seiring dengan penambahan pemendekan. Bt 1, bt 2, bt 3 dengan penambahan pemendekan nilai dip sesarnya semakin naik.

\section{Manfaat Percobaan Sandbox}

Sandbox modeling mempunyai manfaat, antara lain:

1. Memodelkan sistem tektonik pada kerak bumi, konfigurasi struktur dan parameter lain.

2. Memodelkan perkembangan sesar pada skala cekungan hidrokarbon dan pembentukan sesar di permukaan bumi.

3. Memodelkan sesar kaitannya dengan sistem kegempaan suatu daerah. 


\section{Teknik, 36 (1), 2015, 45-53}

Tabel 4. Pemendekan, sudut prowedge, dan spasi sesar

\begin{tabular}{|c|c|c|c|c|c|c|c|c|c|c|c|}
\hline \multirow[t]{2}{*}{$\begin{array}{c}\text { Pemend } \\
\text { ekan } \\
(\%) \\
\end{array}$} & \multicolumn{2}{|c|}{$\begin{array}{c}\text { Sudut } \\
\text { Prowedge } \\
(\alpha) \text { (derajat) }\end{array}$} & \multicolumn{3}{|c|}{$\begin{array}{c}\text { spasi sesar pada } \\
\text { penampang ds }(\mathrm{cm})\end{array}$} & \multicolumn{6}{|c|}{ spasi sesar pada penampang du $(\mathrm{cm})$} \\
\hline & ds & $\mathrm{du}$ & $\begin{array}{l}\text { tf1- } \\
\text { tf2 }\end{array}$ & $\begin{array}{l}\text { tf2- } \\
\text { tf3 }\end{array}$ & $\begin{array}{l}\text { tf3- } \\
\text { tf5 }\end{array}$ & $\mathrm{tf} 1-\mathrm{tf} 2$ & $\mathrm{tf} 2-\mathrm{tf} 3$ & $\mathrm{tf} 3-\mathrm{tf} 5$ & $\mathrm{tf5}-\mathrm{tf} 4$ & $\mathrm{tf} 4-\mathrm{tf6}$ & tf1-tf7 \\
\hline 10,5 & 13 & 22 & 1,3 & & & 1,54 & 1,54 & & & & \\
\hline 21 & 7 & 12 & 1,47 & 1,96 & & 1,7 & 1,7 & 1,97 & 1,88 & & \\
\hline 28 & 7 & 8 & 1,93 & 2,622 & 2,95 & 1,49 & 1,49 & 1,84 & 1,66 & 2,64 & $\begin{array}{r}1,8 \\
2\end{array}$ \\
\hline
\end{tabular}

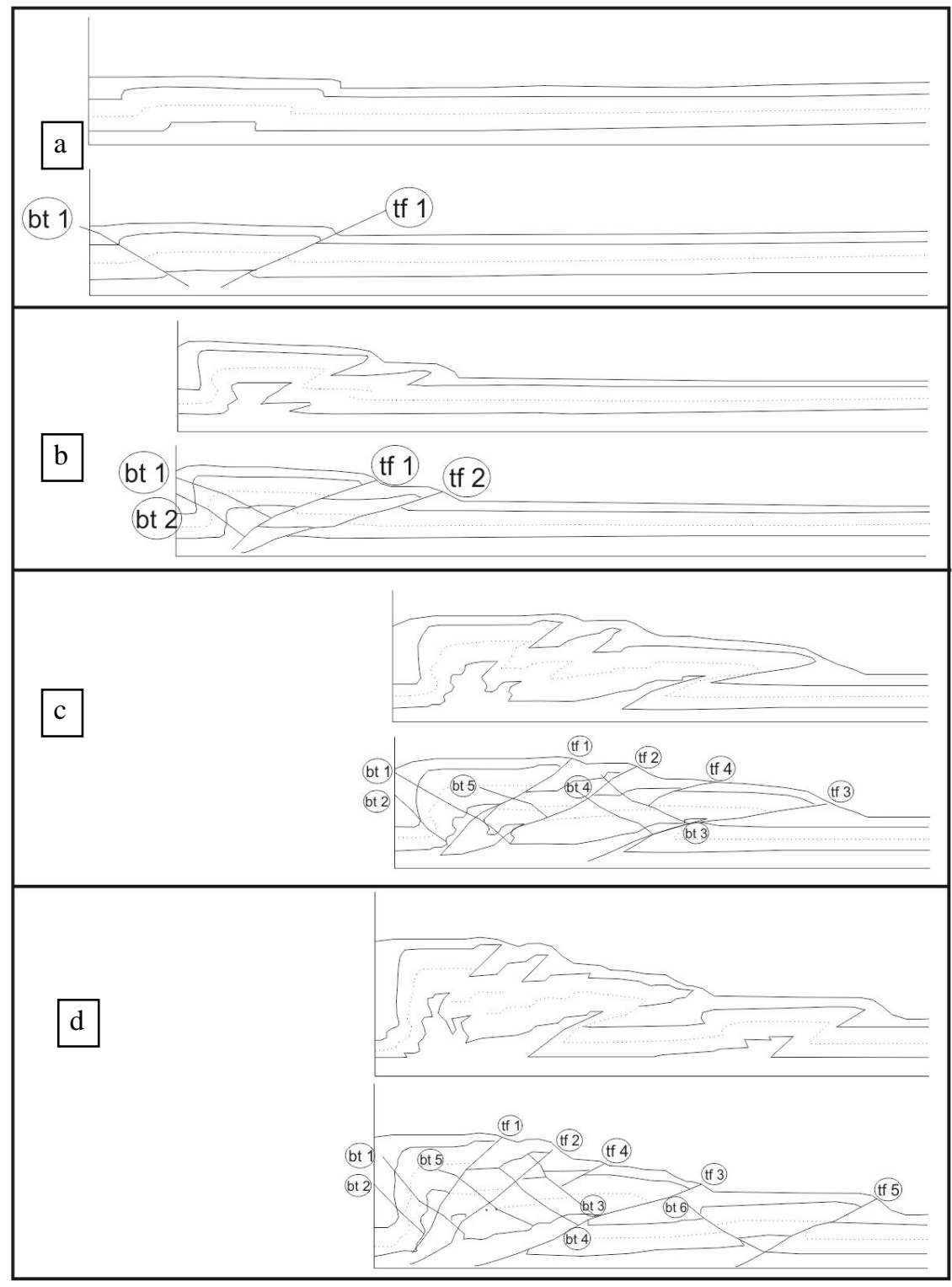

Gambar 3. Sekuen hasil percobaan kompresi penampang ds dengan a). Pemendekan 3,5\% b). Pemendekan $10,5 \%$ c). Pemendekan $21 \%$ d). Pemendekan $28 \%$. 


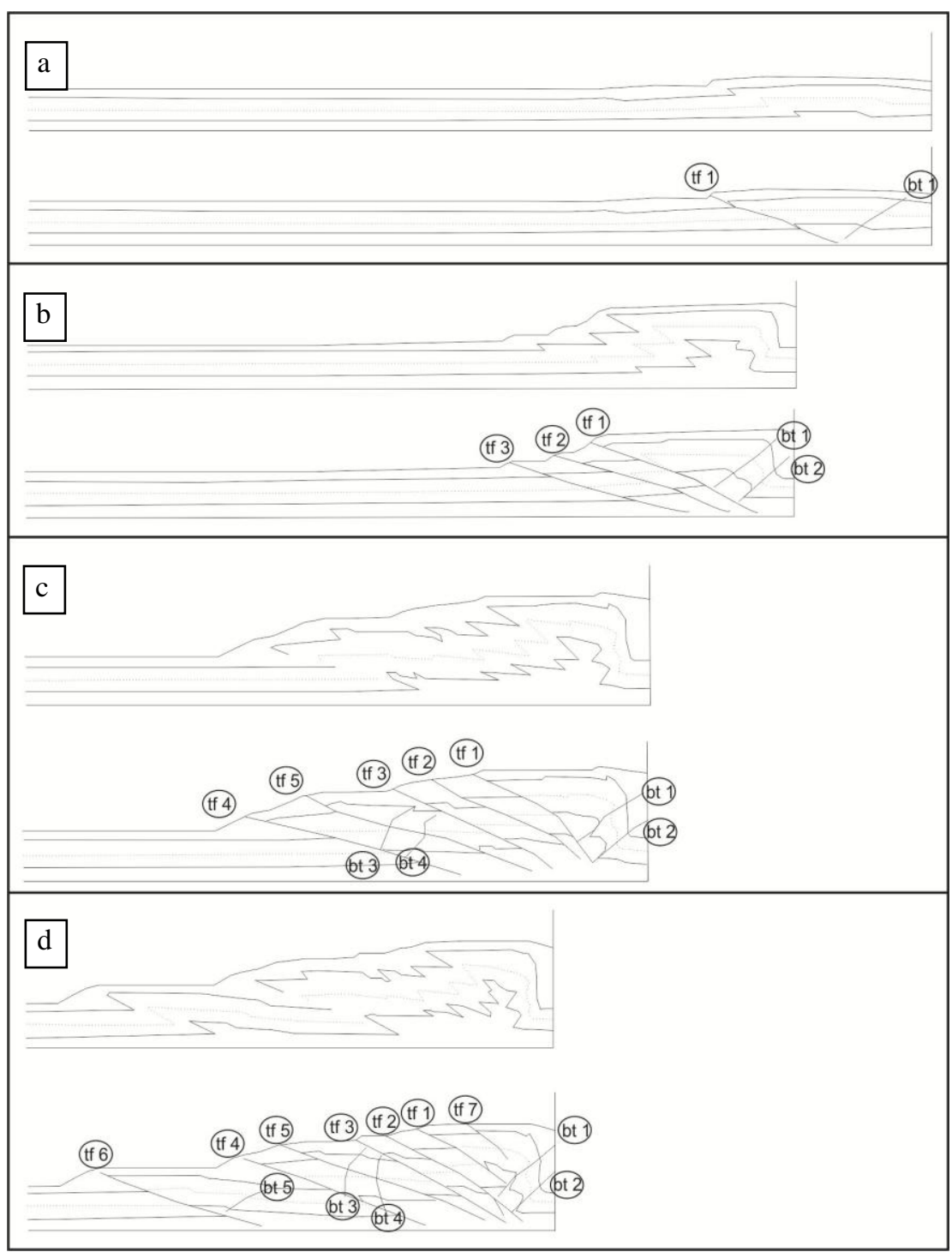

Gambar 4. Sekuen hasil percobaan kompresi penampang du dengan a). Pemendekan 3,5\% b). Pemendekan 10,5\% c). Pemendekan $21 \%$ d). Pemendekan $28 \%$.

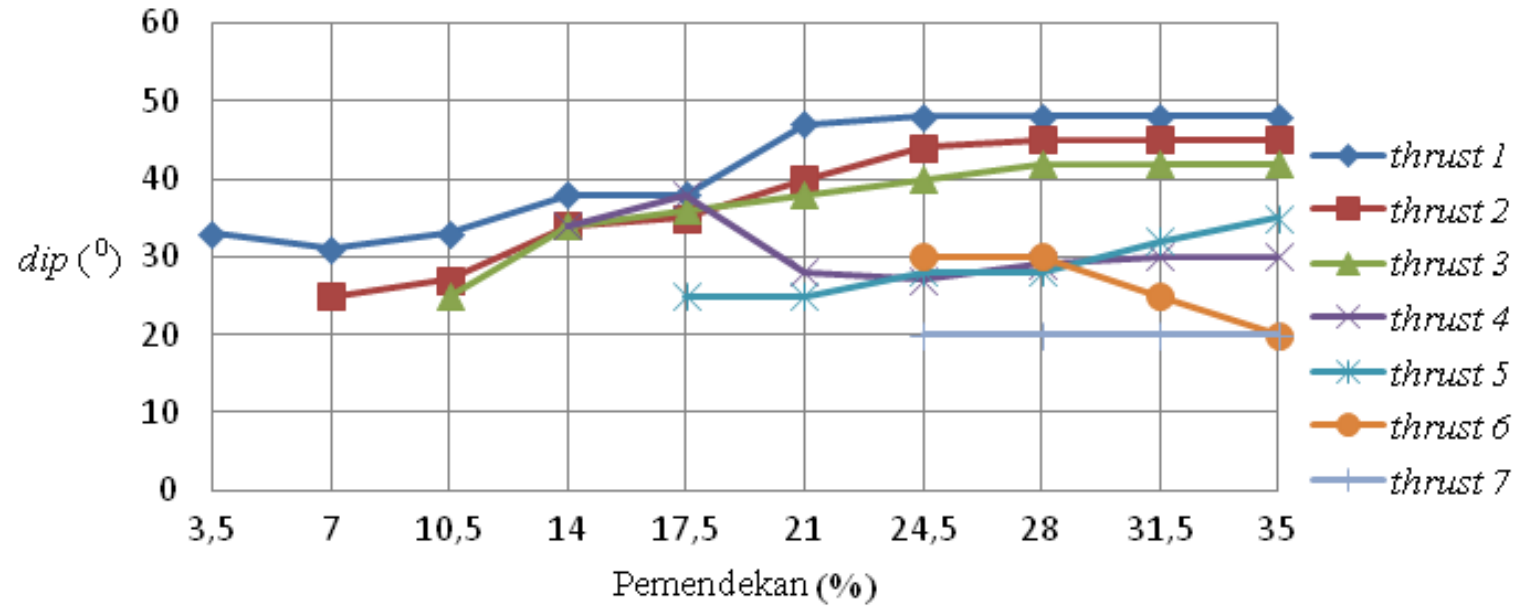

Gambar 5. Perbandingan thrust fault, pemendekan dan dip sesar (dinding utara) 


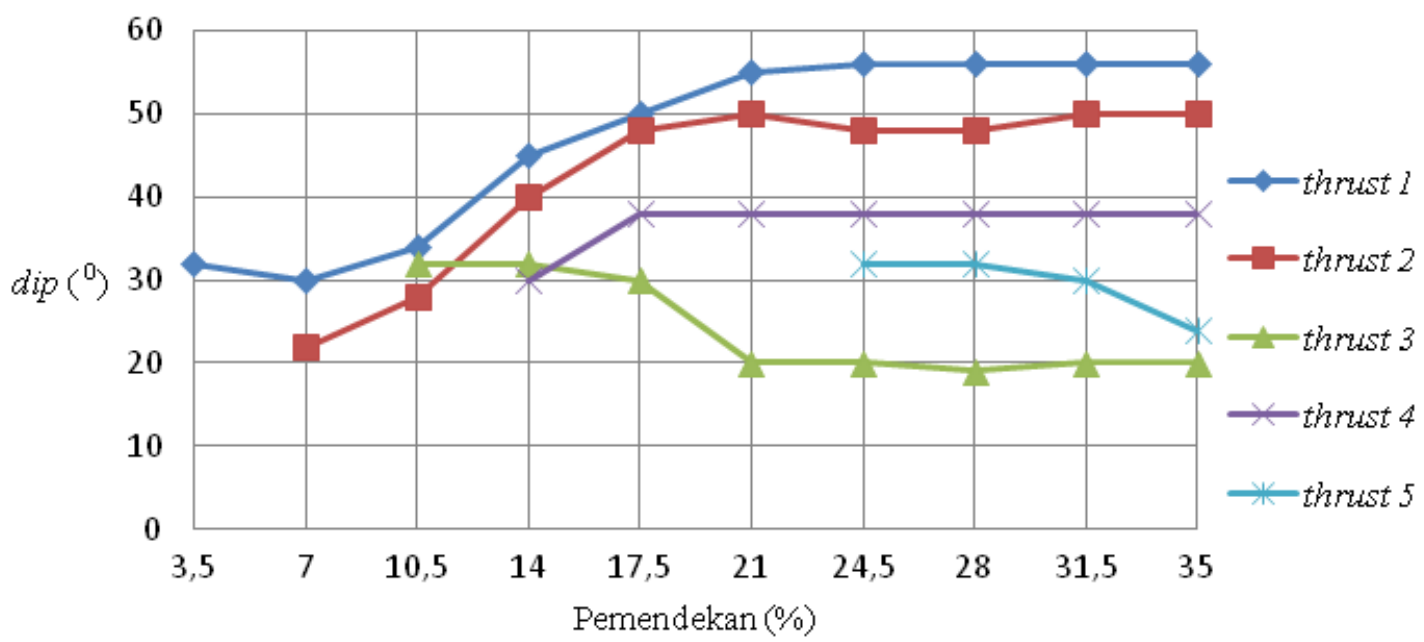

Gambar 6. Perbandingan thrust fault, pemendekan dan dip sesar (dinding selatan)

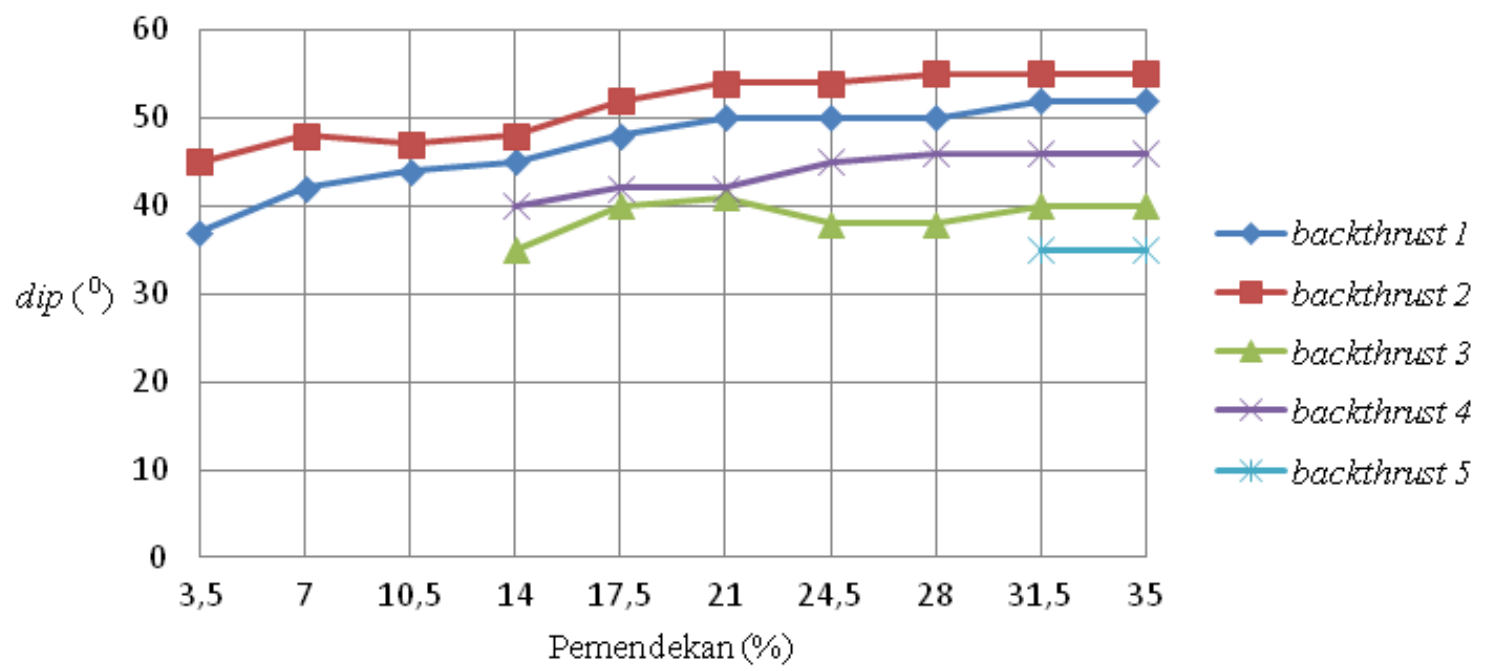

Gambar 7. Perbandingan backthrust fault, pemendekan dan dip sesar (dinding utara)

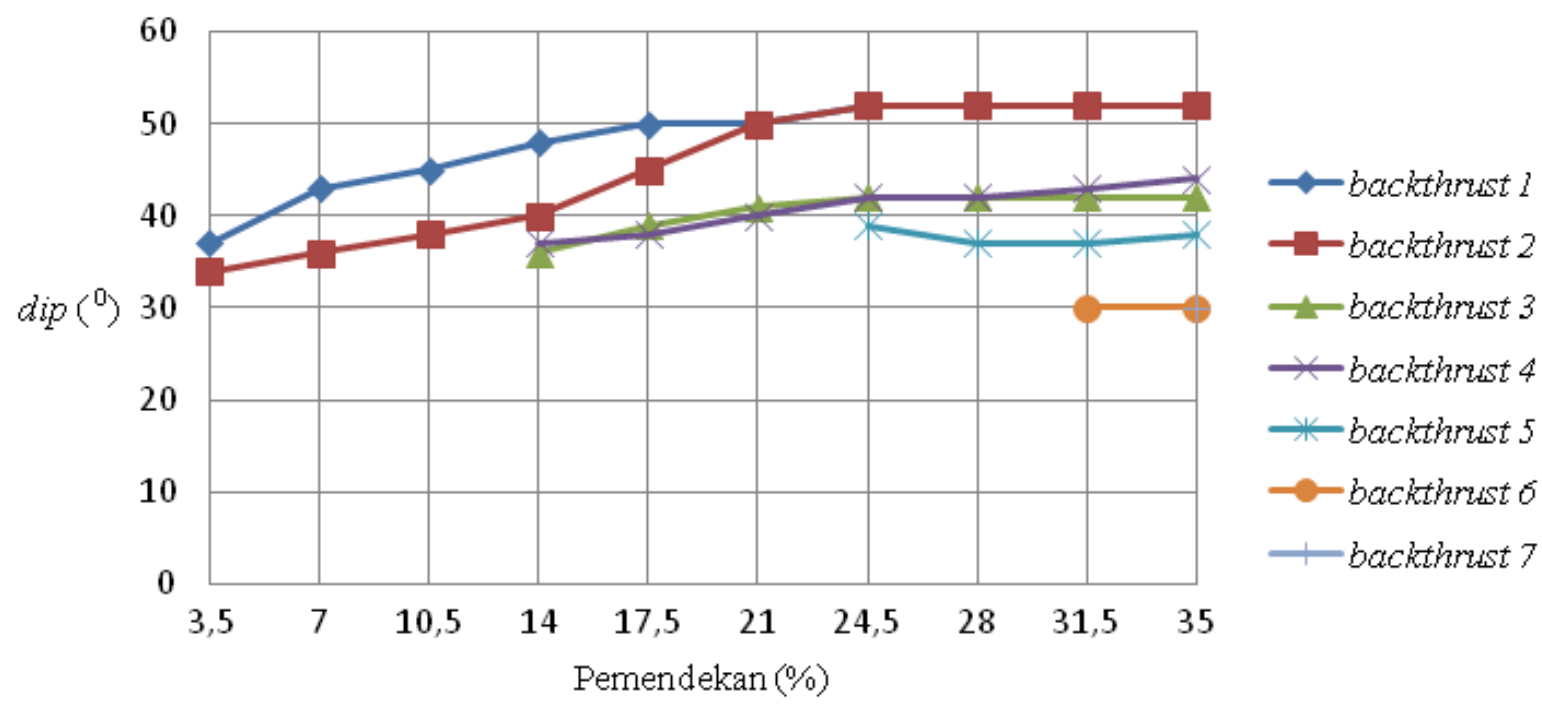

Gambar 8. Perbandingan backthrust fault, pemendekan dan dip sesar (dinding selatan) 


\section{Teknik, 36 (1), 2015, 45-53}

\section{Kesimpulan}

Permodelan analog sandbox berhasil dibuat dengan tahapan pekerjaan dilakukan di Bandung dan di Semarang. Permodelan analog sandbox dibuat dengan satu sumbu yang bias digunakan untuk permodelan regim tektonik konvergen dan divergen. Bahan durallium sebagai basal detachment mempunyai komposisi aluminium dengan tembaga $4 \%$.

Sesar yang terbentuk berupa thrust dan backthrust yang mengalami imbrikasi dengan dipengaruhi oleh basal detachment. Thrust yang terbentuk berupa imbrikasi dengan perkembangan ke depan (forward breaking thrust).Thrust akan berkembang lebih lanjut membentuk reverse fault dengan bentuk drag yang concave.

Percobaan ini menghasilkan tiga zona ridge yaitu ridge pertama (ZR1) (kelurusan no. 1, 4, dan 5), ridge kedua (ZR2) (kelurusan no 9) dan ridge ketiga (ZR3) (kelurusan no. 10). Jarak antar ridge sekitar 5 $\mathrm{cm}$. Setiap awal pembentukan zona ridge akan membentuk lipatan dengan mekanisme fault propagation folding, lipatan ini akan berubah arah lapisan seiringan dengan propagasi thrust lebih lanjut.

\section{Ucapan Terima Kasih}

Terima kasih disampaikan kepada Fakultas Teknik Undip yang telah mendanai penelitian ini.

\section{DaftarPustaka}

Hubbert, M.K. (1951). Theory of Scale Model as Applied to The Study of Geologic Structures. Geological Society of America. Vol.48, p.14591520 .

Bigi, S, dkk. (2010). Load and unload as interference factors on cyclical behavior and kinematics of coulomb wedges: Insights from sandbox experiments. Journal of Structural Geologi 32, hal. 28-44.

McClay, K. (1990). Deformation Mechanics in Analoque Models of Extensional Fault Systems. Geological Society Special Publication 54, p. 445-454.

McClay, K. (1996). Structural Geology, Short Course fo CONOCO, Jakarta, Indonesia, Fault Dynamic Research Group, Geology Dept. Royal Holloway University of London, England, h.25-38.

Purwasasmita, M. (2000). Konsep Teknologi, Tahap Persiapan Bersama, Institut Teknologi Bandung.

Sapiie, B. dan Harsolumakso, A.H. (2000). Pemodelan Analog untuk Proses Pembentukan Struktur Geologi. v.32, No. 3, Departemen Teknik Geologi, Institut Teknologi Bandung. 